\title{
Performances of two pilot decentralized wastewater treatment plants used to treat low-strength wastewater
}

\author{
Julliana Alves da Silva, ${ }^{\mathrm{a}, *}$, Arnaldo Sarti ${ }^{\mathrm{b}}$, Gustavo Henrique Ribeiro da Silva ${ }^{\mathrm{a}}$ \\ ${ }^{a}$ Department of Civil and Environmental Engineering, The College of Engineering Bauru, UNESP - Universidade Estadual Paulista, \\ Av. Eng. Luiz Edmundo Carrijo Coube, 14-01, 17033-360, Bauru, SP, Brazil, Tel. +55 143103 6000; \\ emails: jualves.bio@gmail.com (J.A.da Silva), gustavoribeiro@feb.unesp.br (G.H.R.da Silva) \\ ${ }^{b}$ Department of Biochemistry and Chemical Technology, Institute of Chemistry, UNESP - Universidade Estadual Paulista, \\ Campus Araraquara, Rua Prof. Francisco Degni, 55, 14800-900, Araraquara, SP, Brazil, Tel. +55 163301 9860; \\ email: arnaldosarti@iq.unesp.br
}

Received 10 January 2017; Accepted 6 October 2017

\section{A B S T R A C T}

The performances of an anaerobic/aerobic baffled reactor (AABR) and a horizontal subsurface flow constructed wetlands (HFCW) have been investigated. In this study, both systems were operated in parallel using the same source of domestic low-strength wastewater $\left(0.06-0.61 \mathrm{~kg} \mathrm{COD} \mathrm{m}^{3} \mathrm{~d}^{-1}\right)$. The inlet concentrations, expressed as chemical oxygen demand (COD), ranged from 105 to $381 \mathrm{mg} \mathrm{COD} \mathrm{L}^{-1}$. The outlet concentrations ranged from 12 to $147 \mathrm{mg} \mathrm{COD} \mathrm{L}^{-1}$ in the AABR and from 7 to $88 \mathrm{mg} \mathrm{COD} \mathrm{L}^{-1}$ in the HFCW. The AABR and HFCW achieved $78 \% \pm 9 \%$ and $82 \% \pm 9 \%$ COD average removal rates, respectively. To compare the results, a statistical test (significance level of 0.05) was used and showed no significant difference between the systems in terms of organic matter and total suspended solids (TSS) removal. In addition, this study addressed energy costs and treatment capacity per area for both wastewater treatment systems that were studied independently with capacities for 20 habitants, and showed lower energy consumptions per month when compared with a domestic electric shower generally used by a sample Brazilian family consisting of four members.

Keywords: Anaerobic baffled reactor; Aerobic chamber; Horizontal subsurface flow constructed wetlands; Sanitary wastewater; Energy cost

\footnotetext{
* Corresponding author.
}

Presented at the 13th IWA Specialized Conference on Small Water and Wastewater Systems \& 5th IWA Specialized Conference on Resources-Oriented Sanitation, 14-16 September, 2016, Athens, Greece. 